\title{
Synthesis and Cyclization of some N-(2-Pyridyl) Anthranilic Acids
}

\author{
Rafid k. Jameel Azam A. AL-Hadedi \\ Department of Chemistry \\ College of Science \\ Mosul University
}

(Received 24/12/2009; Accepted 13/ 7 /2010)

\begin{abstract}
A series of N-(2-Pyridyl) anthranilic acids (Ia-f) have been synthesized by Ullmann reaction. Cyclization of $(\mathrm{Ib}, \mathrm{d}, \mathrm{f})$ by phosphorusoxy chloride $\left(\mathrm{POCl}_{3}\right)$ gives substituted 5chlorobenzo $[\mathrm{b}][1,8]$ naphthyridine compounds. The reaction progress was followed by thin layer chromatography (TLC), rate flow $\left(\mathrm{R}_{\mathrm{f}}\right)$ values was recorded, spectral data (IR) and (U.V) were recorded. Elemental analysis (CHNS) and gas chromatography-mass spectrometery (GC/MS) were carried out for some of the synthesized compounds.
\end{abstract}

\section{تحضير وحولفة بضن مركبلت N - (2 - بربطل) حامض الانشرالنيليك}

\section{الملغص}

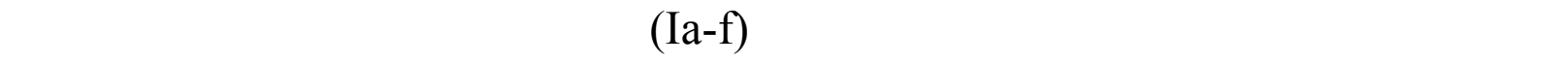
عملية الحولةة لبعض تلك الحوامض (Ib,d,f) بلستخدل اوكسي كلوريد الفنفور(

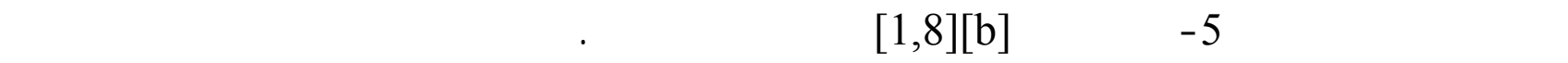

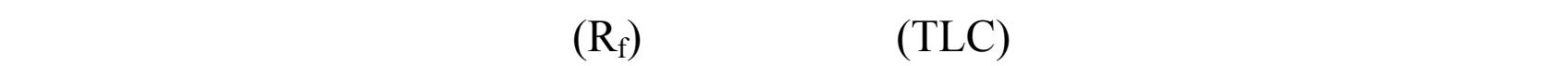

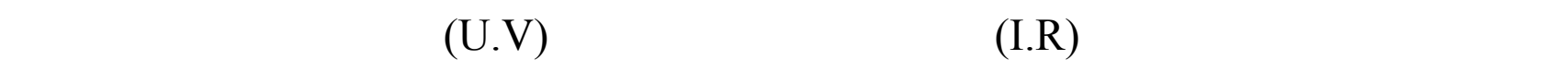
أيضاً لستخدلم التحليل الدقق للعناصر (CHNS) وكروموتوكرافيا غ از طي ف الكتل ـة (GC/MS) ف مي تشخيص واثبت بعض هذه المركبلت.

\section{INTRODUCTION}

Biochemistry of anthranilic acid was reported (Nelson, 2000). Some anthranilic acid derivatives show anticancer activity (Maria et al., 2004; Cenzo et al., 2005). The "Ullmann type" reactions include copper - catalyzed nucleophilic aromatic substitution between various nucleophiles (e.g. substituted aromatic amines) with aryl halides to give substituted anthranilic acids (Kwong et al., 2002; Wolf et al., 2006). Cyclization of anthranilic acid derivatives gave different types of heterocyclic compounds (Per, 2004). Many of naphthyridine derivatives were synthesized by researchers and their biological activity was evaluated and used in different fields. It was used as antimalarial (Zheng et al., 1979), 
treatment of diseases involving enzymes tissues destruction (Skotnicki and Gilman, 1989), Antihypertensive (Ferrarini et al., 1990), antimicrobial (Antoni et al., 2003), antitumor (Tsuzuki et al., 2004), antiinflammatory; analgesic; Antipyretic (Glancarlo et al., 2005) agents, and chemotherapy of infection diseases of human including aids and some of new 1, 8-naphthyridine derivatives including benzo [b]1,8] naphthyridine have recently been patented as growth regulator, fungicides, bactericides, herbicides, insecticides (Tangali et al., 2006).

This work presents successful cyclization method of the new N-(2-Pyridyl) anthranilic acids by $\left(\mathrm{POCl}_{3}\right)$ to give 5 -Chlorobenzo $[\mathrm{b}][1,8]$ naphthyridine compounds.

\section{EXPERIMENTAL}

Uncorrected melting point was determined using electrothermal IA9000 digital-series melting point (1988) apparatus. I.R spectra were recorded on FTIR - Tensor 27- Burker Co., Germany 2003, using KBr discs. U.V Spectra were measured on Shimadzu UV-1650Pc, U.V -Visible recording spectrophotometer. Elemental analysis was measured on Elementer Vario EL III (CHNS) (I.I.T Roorkee, India). Mass Spectra measured on perkin Elmer Clarus 500 Gas chromatography mass spectrometer (I.I.T Roorkee, India).

Synthesis of N-(2-Pyridyl) anthranilic acids (Vogel, 1972).

Two methods are used to prepare these acids: The first method include using of chloropyridine compounds and anthranilic acid to prepare of: Ia $=\mathrm{N}-(2$-pyridyl)anthranilic acid. $\mathrm{Ib}=\mathrm{N}-(6-$ Methoxy-2-pyridyl)anthranilic acid.

N-(2-Pyridyl)anthranilic acid (Ia) : (General procedure)

In (1) liter round bottomed flask equipped with air condenser a mixture of $(0.14$ mole, $16 \mathrm{~g})$ of 2-chloropyridine, $(0.075$ mole, $10.3 \mathrm{~g})$ of anthranilic acid, $(0.075$ mole, 10.35 $\mathrm{g})$ of anhydrous potassium carbonate and (1g) of cupric oxide was placed. The mixture was refluxed in an oil bath at $\left(120-130{ }^{\circ} \mathrm{C}\right)$ for $(15 \mathrm{hrs}$.). Allowed to cool, the excess of chloropyridine was removed by steam distillation and $(1 \mathrm{~g})$ of charcoal was added to the residual solution. The mixture was boiled for $(30 \mathrm{~min})$ and filtered at the pump. Mixture of (1:1) hydrochloric acid and water was added to the filtrate with stirring until neutral-acidic medium was achieved. Then the precipitated acid was filtered with suction and washed with cold water for many times, and dried in the air. Recrystallization from ethanol gave pale green acid (Ia), m.p $=210-212^{\circ} \mathrm{C}$; (yield, 47\%), (Table 1).

Using the above procedure, by reacting of 2-Chloro-6-methoxypyridine with anthranilic acid, gave N-(6-Methoxy-2-pyridyl)anthranilic acid (Ib), m.p =196-198 ${ }^{\circ} \mathrm{C}$; (yield, 31\%), (Table 1), (Figure 1), (Scheme 1).

The second method includes the use of 2-Aminopyridine and halo benzoic acid compounds for preparation of:

Ic $=\mathrm{N}-(6-$ Methyl-2-pyridyl)anthranilic acid .

Id = 4-Chloro-N-(6-methyl-2-pyridyl)anthranilic acid .

$\mathrm{Ie}=\mathrm{N}$-(4-Methyl-2-pyridyl)anthranilic acid .

If $=4$-Chloro-N-(4-methyl -2-pyridyl)anthranilic acid .

$\mathrm{Ia}=\mathrm{N}-(2-$ Pyridyl)anthranilic acid. 
N- (6-Methyl-2-pyridyl) anthranilic acid (Ic): (General procedure)

(0.1 mole, $10.8 \mathrm{~g})$ of 2-Amino-6-picoline, (0.05 mole, $10.05 \mathrm{~g}$.) of o-bromo benzoic acid, (0.05 mole, $6.9 \mathrm{~g})$ of anhydrous potassium carbonate and (1g) of cupric oxide were mixed together in appropriate flask. The mixture was refluxed in oil bath for $(3.5 \mathrm{hrs}$. $)$ at $\left(130-140{ }^{\circ} \mathrm{C}\right)$. The mixture was steam distilled to remove the excess amine and $(1 \mathrm{~g})$ of charcoal was added. The mixture was boiled for (30 min.) and filtered. A mixture of (1:1) hydrochloric acid: water was added, until $\mathrm{pH} \approx 4$ (Besly and Goldberg, 1954). The solid product was recrystallized from methanol to give greenish white acid (Ic). m.p $=125-127^{\circ} \mathrm{C}$; (yield, 63\%); (Table 1); CHNS analysis (\%), calculated (found) for $\mathrm{C}_{13} \mathrm{H}_{12} \mathrm{~N}_{2} \mathrm{O}_{2}$, C:68.42(67.83), H:5.26(5.64), N:12.28 (12.79).

The above procedure was used to prepare the compound (Id) from (2-Amino-6picoline) and (2,4-Dichlorobenzoic acid); (Ie) from (2-Amino-4-picoline) and (obromobenzoic acid); (If) from (2-Amino-4-picoline) and (2,4-Dichlorobenzoic acid), while compound (Ia) was prepared from (2-Amino pyridine) and (o-bromobenzoic acid). The physical constants and the spectral data (IR) of these acids were listed in table (1); mass spectra of the compound (Id) was given, (figure 2) and the fragmentation pattern was showed in scheme (2).

Synthesis of substituted 5-chlorobenzo [b][1,8] naphthyridine (Besly and Goldberg, 1954; Adrine and Bruce, 1955,1942) .

\section{5-Chloro-2-methoxybenzo [b][1,8] naphthyridine (IIa): (General procedure)}

In a round-bottomed flask fitted with water condenser (calcium chloride drying tube was used), (1.2 g, 0.0049 mole) of (Ib) was placed, (10 ml, 0.107 mole) of phosphorusoxy chloride $\left(\mathrm{POCl}_{3}\right)$ was slowly added. The mixture was heated for $(30 \mathrm{~min}$.) in an water bath. The mixture was heated in oil bath at $\left(130-140^{\circ} \mathrm{C}\right)$ for $(5 \mathrm{hrs}$. $)$, then the excess of $\left(\mathrm{POCl}_{3}\right)$ was removed by vacuum distillation in an oil bath $\left.(80-100 \mathrm{~mm} \mathrm{Hg}) / 50-60^{\circ} \mathrm{C}\right)$. The residue was slowly poured on a well-stirred mixture of $(25 \mathrm{ml}$.) conc. ammonia solution, $(50 \mathrm{~g}$. $)$ of ice and $(50 \mathrm{ml}$.) of chloroform. With continuous cooling a little ice and conc. ammonia solution was added until the solution become basic. The final mixture was allowed to stay in ice bath (over night), when no more undissolved solid remain, the organic layer was separated, and the aqueous layer was extracted with an additional $(20 \mathrm{ml})$ of chloroform. The organic layer was dried by calcium chloride. After filtration the solvent was removed by vacuum distillation until dryness. 5-chloro-2-methoxybenoz [b][1,8] naphthyridine (Пa), m. $\mathrm{p}=118-120{ }^{\circ} \mathrm{C}$; (yield, 39\%); (Table 1,2). CHNS, analysis (\%), calculated (found): C: 63.8 (65.94), H: 3.68 (3.43), N: 11.45 (11.07) was obtained.

The above procedure, by using ( $3 \mathrm{~g}, 0.0114 \mathrm{~mole})$ of (Id) and ( $21 \mathrm{ml}, 0.228 \mathrm{~mole})$ of $\left(\mathrm{POCl}_{3}\right)$ gave the compound 5,8-dichloro-2-methyl benzo [b][1,8] naphthyridine (IIb); m.p $=158-160{ }^{\circ} \mathrm{C}$; (yield, 54\%); (Table 1 and 2); (Fig. 3); (Scheme 3). While the compound 5,8-dichloro-4-methylbenzo [b][1,8] naphthyridine (IIc) was prepared from $(0.3 \mathrm{~g} .0 .0011$ mole) of (If) and (5 ml, 0.0536 mole) of $\left(\mathrm{POCl}_{3}\right) . \mathrm{M} \cdot \mathrm{p}=175-177^{\circ} \mathrm{C}$; (yield, $\left.30 \%\right)$, (Table 1 and 2). 
Table 1: Physical properties and spectral data (I.R , $\mathrm{cm}^{-1}, \mathrm{KBr}$ ) for compounds (Ia-f, IIa-c).

\begin{tabular}{|c|c|c|c|c|c|c|c|c|c|c|}
\hline $\begin{array}{l}\text { Comp. } \\
\text { No. }\end{array}$ & $\mathbf{m} \cdot \mathbf{p},{ }^{\circ} \mathrm{C}$ & $\mathbf{R}_{\mathbf{f}}$ & Color & $\begin{array}{l}\text { Yield } \\
(\%)\end{array}$ & $\begin{array}{l}\text { OH } \\
\text { Str. } \\
\text { (br.) }\end{array}$ & $\begin{array}{c}\text { NH Str. } \\
\text { (br.) }\end{array}$ & $\begin{array}{l}\mathbf{C}=\mathbf{O} \\
\text { Str. }\end{array}$ & $\begin{array}{l}\mathrm{C}=\mathrm{N} \\
\text { Str. }\end{array}$ & $\begin{array}{c}\mathrm{C}=\mathrm{C} \\
\text { Str. } \\
\text { (arm.) }\end{array}$ & Others \\
\hline Ia & $210-212$ & 0.425 & Pale green & 47 & 3546 & 3414 & 1697 & 1640 & 1609 & --------- \\
\hline Ib & 196-198 & 0.429 & Brown & 31 & 3547 & 3414 & 1667 & 1639 & 1616 & $\begin{aligned} \delta \mathrm{CH}\left(\mathrm{CH}_{3}\right) & =1414 \\
v \mathrm{R}-\mathrm{O}-\mathrm{Ar} & =1235\end{aligned}$ \\
\hline Ic & $125-127$ & 0.478 & $\begin{array}{l}\text { Greenish } \\
\text { white }\end{array}$ & 63 & 3430 & 3329 & 1687 & 1640 & 1609 & $\delta \mathrm{CH}\left(\mathrm{CH}_{3}\right)=1371$ \\
\hline Id & 108-109 & 0.122 & Brown & 38 & 3367 & 3318 & 1682 & 1633 & 1588 & $\begin{array}{c}\delta \mathrm{CH}\left(\mathrm{CH}_{3}\right)=1372 \\
\delta \mathrm{C}-\mathrm{Cl}=735\end{array}$ \\
\hline Ie & $128-130$ & 0.153 & Brown & 59 & 3445 & 3280 & 1682 & 1640 & 1598 & $\delta \mathrm{CH}\left(\mathrm{CH}_{3}\right)=1390$ \\
\hline If & $\begin{array}{l}206-208 \\
\text { Sub. }\end{array}$ & 0.465 & White & 25 & 3550 & 3414 & 1690 & 1649 & 1597 & $\begin{array}{c}\delta \mathrm{CH}\left(\mathrm{CH}_{3}\right)=1382 \\
\delta \mathrm{C}-\mathrm{Cl}=700\end{array}$ \\
\hline IIa & $118-120$ & 0.658 & $\begin{array}{l}\text { Greenish } \\
\text { brown }\end{array}$ & 39 & ------ & --------- & ------ & 1647 & 1604 & $\begin{array}{c}\delta \mathrm{C}-\mathrm{H}\left(\mathrm{CH}_{3}\right)=1374 \\
\delta \mathrm{C}-\mathrm{Cl}=689 \\
v \mathrm{R}-\mathrm{O}-\mathrm{Ar}=1249\end{array}$ \\
\hline IIb & $158-160$ & 0.607 & $\begin{array}{l}\text { Dark } \\
\text { brown }\end{array}$ & 54 & ------ & --------- & ------ & 1652 & 1621 & $\begin{array}{c}\delta \mathrm{C}-\mathrm{H}\left(\mathrm{CH}_{3}\right)=1370 \\
\delta \mathrm{C}-\mathrm{Cl}=697\end{array}$ \\
\hline IIc & $175-177$ & 0.940 & $\begin{array}{c}\text { Yellowish } \\
\text { brown }\end{array}$ & 30 & ------ & --------- & ------ & 1638 & 1617 & $\begin{array}{c}\delta \mathrm{C}-\mathrm{H}\left(\mathrm{CH}_{3}\right)=1390 \\
\delta \mathrm{C}-\mathrm{Cl}=697\end{array}$ \\
\hline
\end{tabular}

Table 2: U.V Spectral data (in [MeOH] ) of compounds (IIa-c).

\begin{tabular}{|c|c|}
\hline Comp. No. & $\lambda \mathbf{m a x}[\mathbf{n m}](\mathbf{l o g} \mathbf{C})$ \\
\hline IIa & $216(4.394), 270(4.114), 344(4.425), 366(4.117)$ \\
\hline IIb & $216(4.396), 238(4.316), 270(4.35), 350(3.707)$ \\
\hline IIc & $209(4.287), 230(4.36), 270(4.03), 348(4.02)$ \\
\hline
\end{tabular}

1, 8-naphthyridine $\lambda \max [\mathrm{nm}](\log \epsilon)$ :

257(3.60), 295(3.65),302(3.79), 307(3.80). 
Synthesis and Cyclization of some........
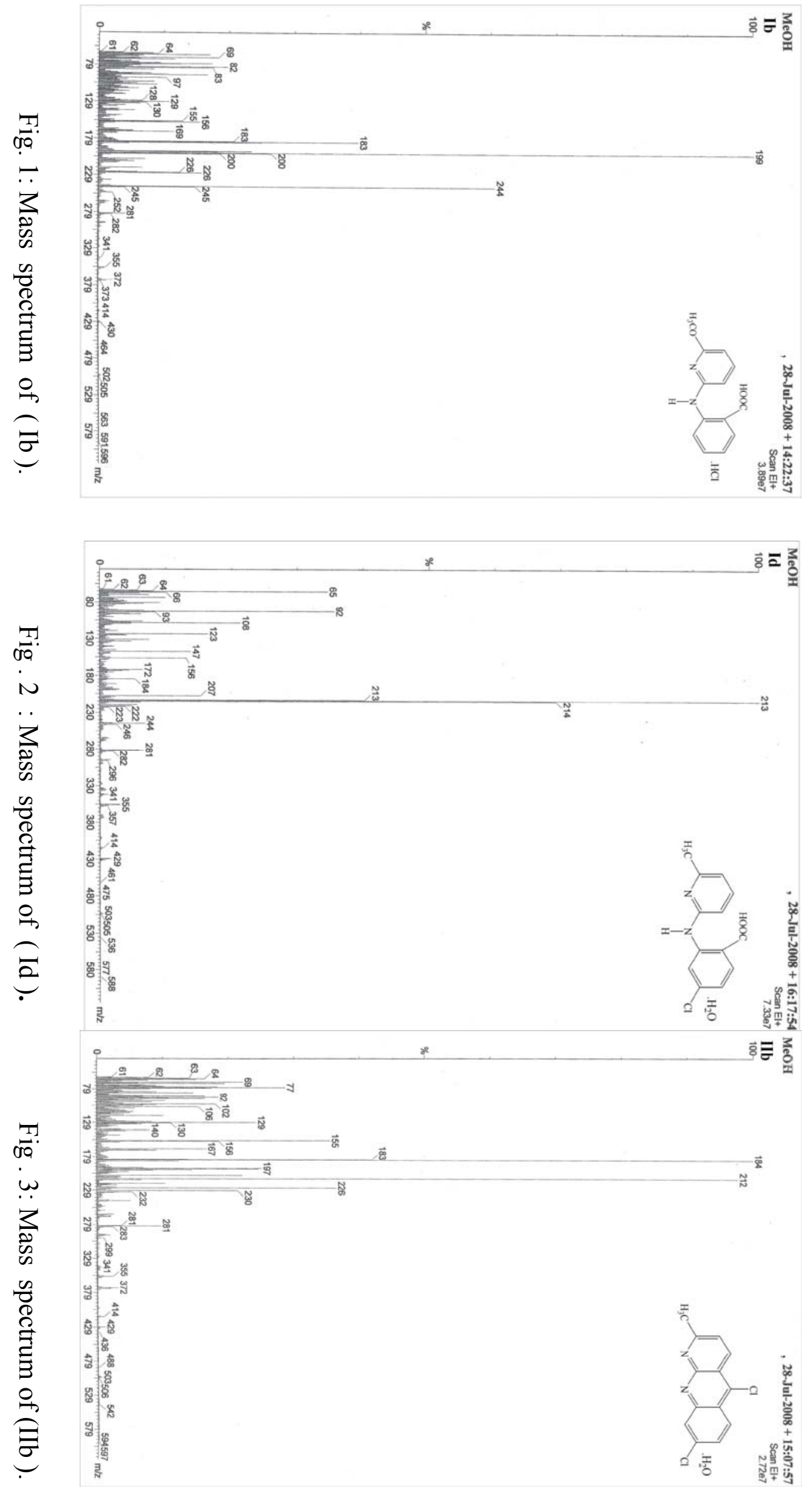
<smiles>COc1cccc(Nc2ccccc2C(=O)O)n1</smiles>

(Ib)

$\mathrm{m} / \mathrm{z} 281(4 \%),(\mathrm{M}+1) 282(2 \%)$<smiles>COc1cccc(/N=C2/C=CC=CC2=C=O)n1</smiles>
$\mathrm{m} / \mathrm{z} 226(23 \%, 26 \%)$

(M-18) $\mathrm{m} / \mathrm{z} 244(61 \%),(\mathrm{M}+1) 245(2 \%, 13 \%)$

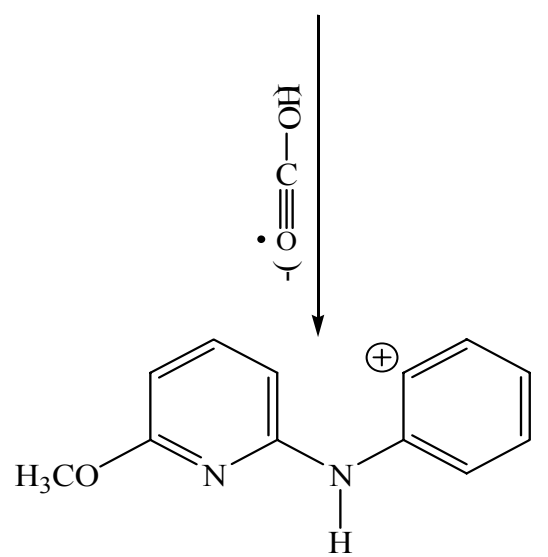

$\mathrm{m} / \mathrm{z} 199(100 \%),(\mathrm{M}+1) 200(26 \%, 29 \%)$<smiles>CCc1cccc(N(c2ccccc2)[C@H](C)CCc2ccccc2)n1</smiles>

$\mathrm{m} / \mathrm{z} 169(12 \%)$<smiles>CC1=[14CH][TlH]C(=Nc2ccccc2)C=C1</smiles>

$\mathrm{m} / \mathrm{z} 156(15 \%)$

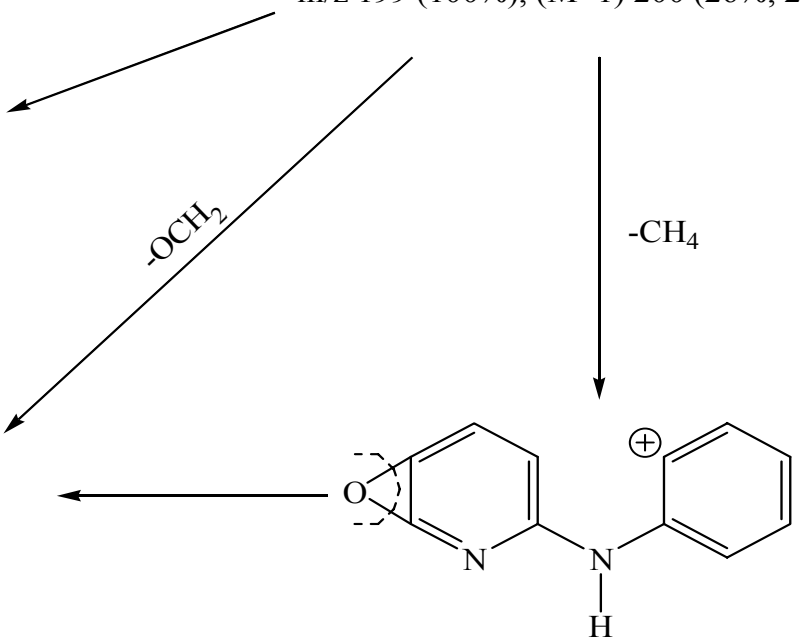

$\mathrm{m} / \mathrm{z} 183(40 \%, 21 \%)$<smiles>[C+]=C/C=N\c1ccccc1</smiles>

$\mathrm{m} / \mathrm{z} 130(7 \%)$

Scheme 1: The fragmentation of compound ( I b ). 
Synthesis and Cyclization of some........

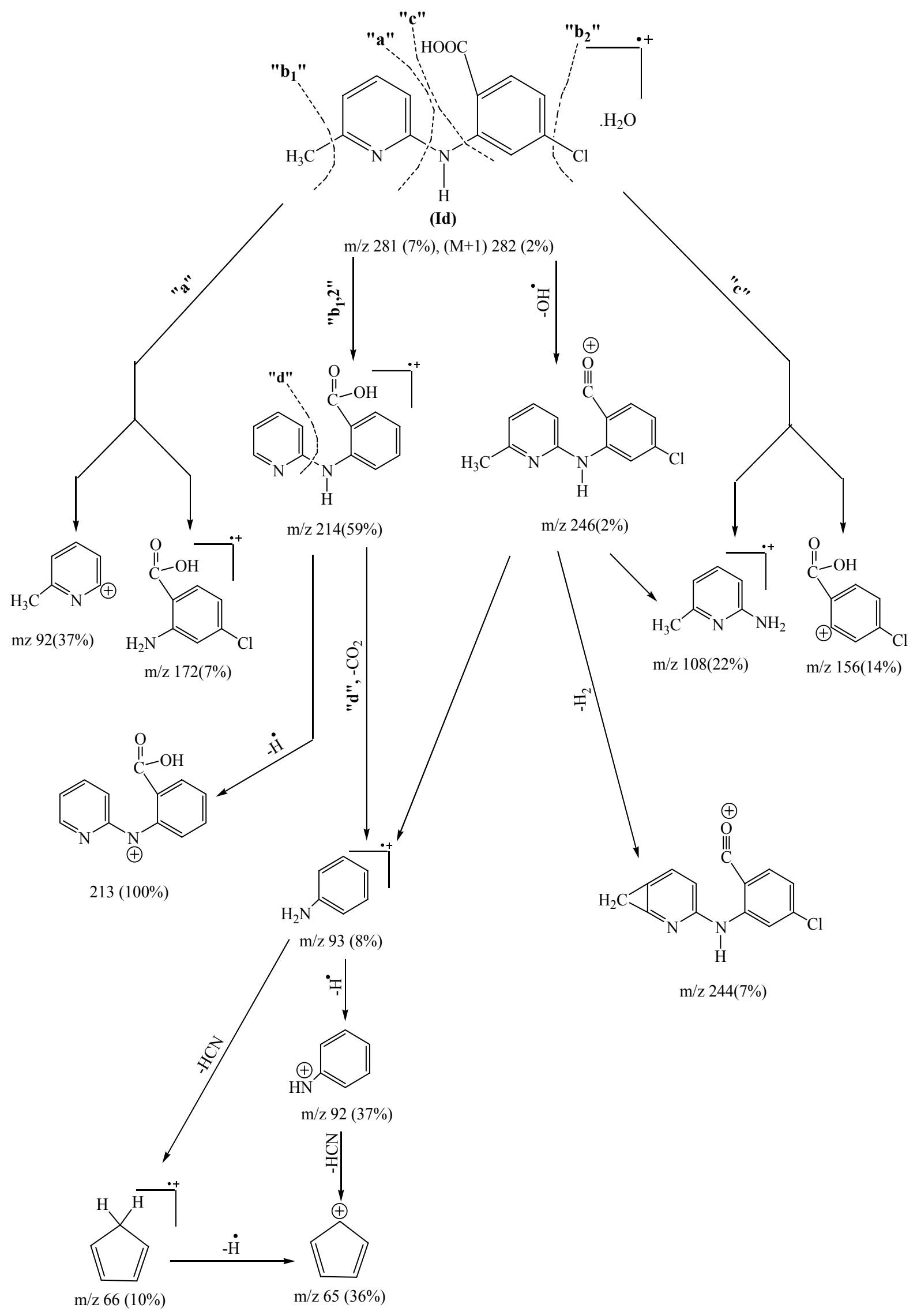

Scheme 2: The fragmentation of compound ( I d ). 


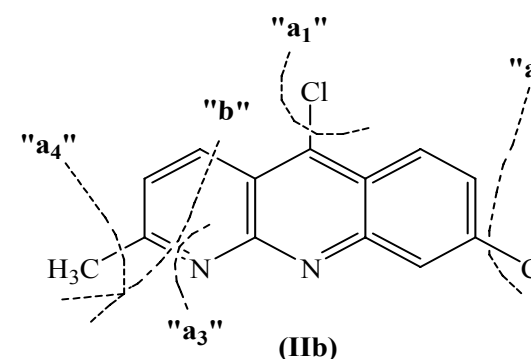

$\mathrm{m} / \mathrm{z} 281(10 \%),(\mathrm{M}+2) 283(2 \%)$

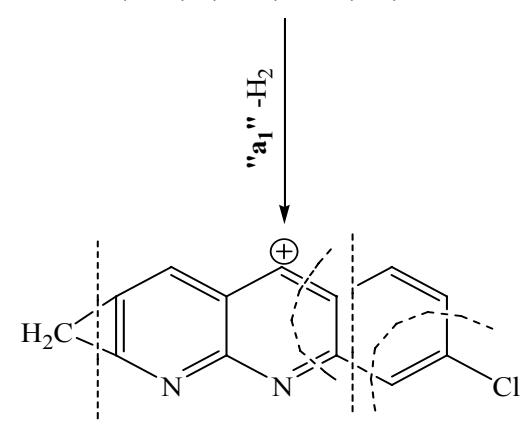

$\mathrm{m} / \mathrm{z} 226(37 \%)$
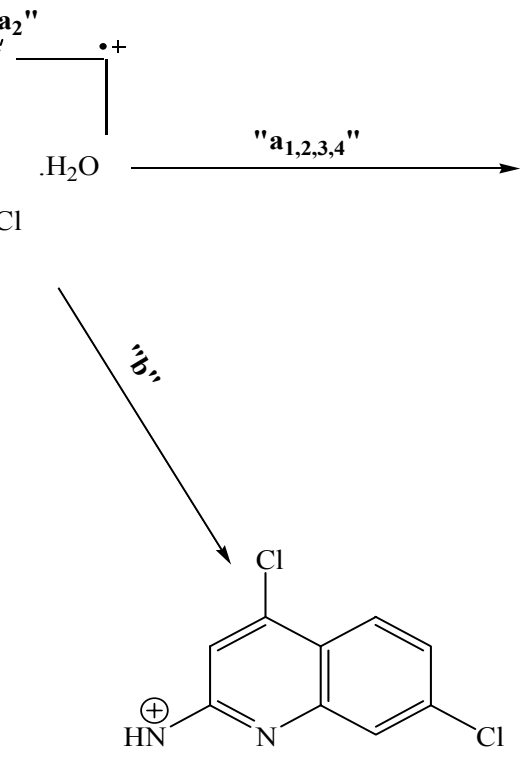

$\mathrm{m} / \mathrm{z} 212(98 \%)$<smiles>c1ccc2ncccc2c1</smiles>

$\mathrm{m} / \mathrm{z} 130(12 \%)$
$\oplus_{\mathrm{CH}_{2} \mathrm{CH}_{2} \mathrm{Cl}}$

$$
\mathrm{m} / \mathrm{z} 64(17 \%)
$$

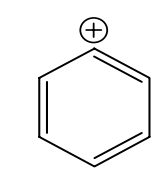

$\mathrm{m} / \mathrm{z} 77(28 \%)$

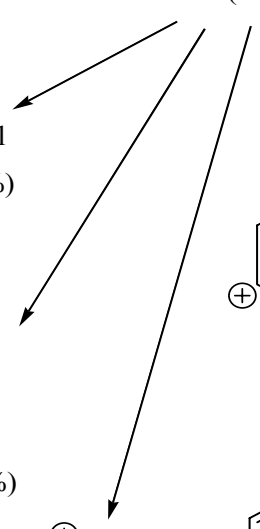

$\oplus_{\mathrm{NH}}^{+}$

$\mathrm{m} / \mathrm{z} 92(18 \%)$

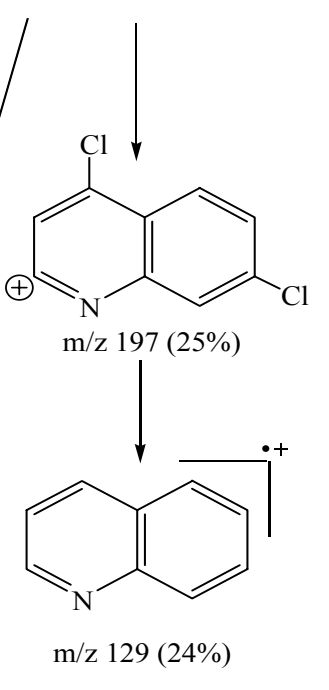

$\mathrm{m} / \mathrm{z} 129(24 \%)$<smiles></smiles>

$\mathrm{m} / \mathrm{z} 183(36 \%)$<smiles>C1=C2C=c3ccccc3=NC2N1</smiles>

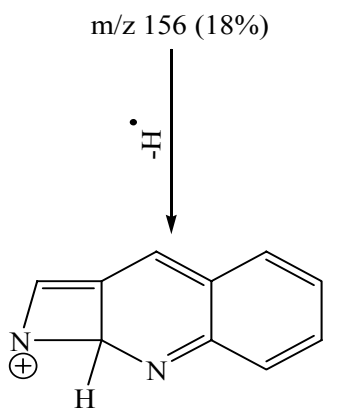

$\mathrm{m} / \mathrm{z} 155(36 \%)$

Scheme 3: The fragmentation of compound ( I I b ).

\section{RESULTS AND DISCUSSION}

\section{Synthesis of N-(2-Pyridyl)anthranilic acids (Ia-f):}

$\mathrm{N}$-(2-pyridyl)anthranilic acids (Ia,b) were prepared by mixing 2-chloropyridine derivatives with anthranilic acid, anhydrous potassium carbonate as a base and cupric oxide as a catalyst, Equation (1). 
<smiles>[R]Oc1cccc([R])n1</smiles>

Equation (1)<smiles>[R]c1cccc(Nc2ccccc2C(=O)O)n1</smiles>

(Ia) $\quad \mathrm{R}=\mathrm{H}$

(Ib) $\mathrm{R}=\mathrm{OCH}_{3}$

$\mathrm{N}$-(2-pyridyl)anthranilic acids (Ia,c-f) were prepared by mixing 2-Amino pyridine derivatives with 2,4-Dichloro or 2-Bromo benzoic acid, anhydrous potassium carbonate as a base and cupric oxide as catalyst, (Equation 2).

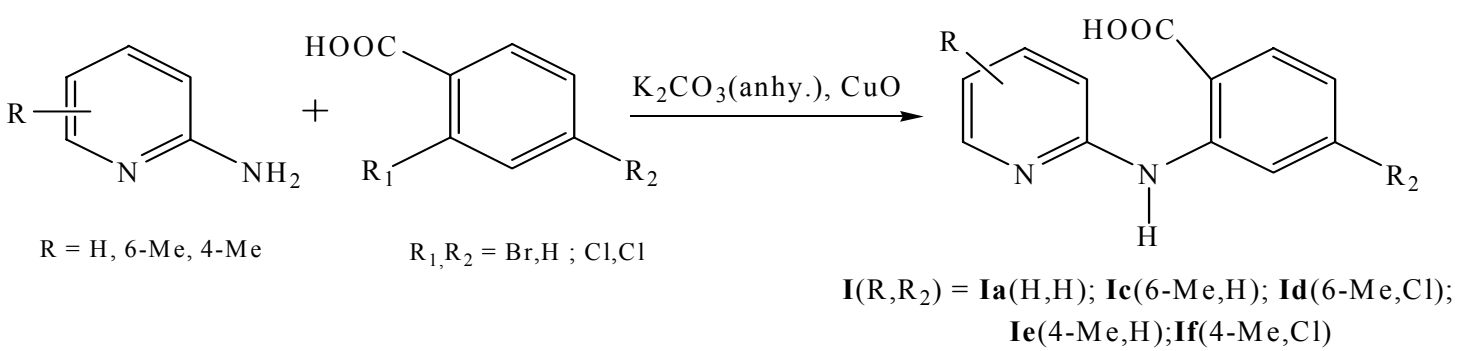

Equation (2)

The structure of acids (Ia-f) was identified by iodate-iodide test (cheronis, 1963) and I.R spectra which showed a main absorption bands at $v(3550-3280) \mathrm{cm}^{-1}$ assigned to (O$\mathrm{H})$ and $(\mathrm{N}-\mathrm{H})$ groups, $(1697-1667) \mathrm{cm}^{-1}$ assigned to $(\mathrm{C}=\mathrm{O})$ and $(1649-1633) \mathrm{cm}^{-1}$ assigned to $(\mathrm{C}=\mathrm{N})$, (Table 1$)$. Elemental analysis were used to identify some of these acids (Ia,c) (see the values in the experimental part ), GC/MS for the compounds (Ib, d) showed that the two acid are formed, figures $(1,2)$; schemes $(1$ and 2$)$.

The figure (1) gave peak bar $(\mathrm{m} / \mathrm{z} 244,61 \%)$ and $(\mathrm{m} / \mathrm{z} 281,4 \%)$, which were assigned to the compound $(\mathrm{Ib})(\mathrm{M} . \mathrm{Wt}=244)$ and $(\mathrm{M}+\mathrm{HCl})$, while the figure $(2)$ gave peak bar $(\mathrm{m} / \mathrm{z}$ $281,7 \%)$ that assigned to the compound (Id) containing one water molecule $(\mathrm{M}+18)$. The suggested fragmentations pattern for both acids (Ib,d) were given in the schemes (1 and 2).

\section{Synthesis of 5-Chlorobenzo [b] $[1,8]$ naphthyridine compounds.}

The compounds (IIa-e) were prepared by cyclization of substituted anthranilic acids $(\mathrm{Ib}, \mathrm{d}, \mathrm{f})$ respectively by using $\left(\mathrm{POCl}_{3}\right)$, (Equition 3$)$.<smiles>[R]c1cc([R])cc(Nc2nc([R3])ccc2C(=O)O)c1</smiles>

$(\mathrm{Ib}, \mathrm{d}, \mathrm{f})$<smiles>[R4]c1cc([R1])c2c(Cl)c3ccc([13CH3])cc3nc2n1</smiles>

(II) R1,R2,R3:(IIa) H,OMe,H; (IIb) $\mathrm{H}, \mathrm{CH} 3, \mathrm{Cl}$; (IIc) $\mathrm{CH} 3, \mathrm{H}, \mathrm{Cl}$.

Equation (3) 
The structure of the compounds (IIa-c) was identified by elements test, (Cheronis; $1963)$ and I.R spectra which shows a main absorption bands at $v(1652-1638) \mathrm{cm}^{-1}$ assigned to $(\mathrm{C}=\mathrm{N}),(1621-1604) \mathrm{cm}^{-1}$ assigned to $(\mathrm{C}=\mathrm{C}$ aromatic $)$, and disappearance of $(\mathrm{C}=\mathrm{O})$ band. A new bands at $(679-689) \mathrm{cm}^{-1}$ assigned to $(\mathrm{C}-\mathrm{Cl})$ and $(749,830,1048,1124) \mathrm{cm}^{-1}$ assigned to naphthyridine cycles (Mohammad, 1994). U.V spectra showed absorption values $(\lambda \max )$ at $(209-366) \mathrm{nm}$ and $(\log \varepsilon)$ values at (4.425-3.707), (Table 2). (The values that fitted 1, 8-naphthyridine moiety given by (katritzky, 1984).

Elemental analysis of the compound (IIa) showed that this compound may contain water or hydrogen chloride molecule. GC/MS of (IIb), Figure (3) shows a peak bar of ( $\mathrm{m} / \mathrm{z}$ $281,10 \%$ ) which assigned to this compound with water molecule i.e. $\mathrm{M}+18$. The suggested fragmentation for this compound was given in the scheme (3).

\section{ACKNOWLEDGMENTS}

This work was supported by college of Science, department of Chemistry. Authors are grate full to prof. S . M . Sondi and Mr. Abdlhaq ( I.I.T Roorkee, India ) for excellent help us in doing CHNS analysis and GC/MS.

\section{REFERENCES}

Adrine, A. ; Bruce, R. (1955), (1942). 9-Aminoacridine. Organic Synthesis, Coll., 3, 53; 22, $5 \mathrm{p}$.

Antonie, M.; Barreau, M.; Descon, C.; Philippe, G. ; Guy, P. (2003). Benzo [b] [1,8] naphthyridine derivatives, their preparation and pharmaceutical compositions as antimicrobical agents. US Pat. 6548506.

Besly, D. M. ; Goldberg, A. A. (1954). Antimalarial 2-Alkoxy-6-chloro-9dialkylaminoalkylamino-1:10-diaza-anthracines, J. Chem. Soc., 2448.

Cenzo, C.; Maria, T.C.; Valentina, L.; Valentina, O. (2005). New anticancer agents based on the anthranilic acid scaffold. Synthesis and evaluation of biological activity. $J$. Med. Chem., 48, 8245.

Cheronis, N. D. ; Entrikin, J. B., (1963). Identification of Organic Compounds, John Wiley $\&$ Sons, Inc. New York. London, Sydney, 115; 72p.

Ferrarini, P. L.; Mori, C.; Primofiore, G.; Settimo, A.D.; Breschi, M.C.; Martinotti, E.; Nieri, P. ; Ciucci, M.C. (1990). Synthesis and $\beta$-blocking activity of (E) - and (Z)iminoethers of 1,8-naphthyridine. Potential antihypertensive agents 4, Eur. J. Med. Chem., 25(6), 489.

Giancarlo, G.; Mario, D.B.; Giogio, R.; Vigilio, B.; Massimiliano, T. ; Elisabetta, B. (2005). 1,8- naphthyridines V. novel N-substituted 5-amino-N, N-diethyl-9-isopropyl $[1,2,4]$ triazolo $[4,3-\mathrm{a}][1,8]$ naphthyridine-6-carboxamides, as potent antiinflammatory and analgesic agents completely devoid of acute gastrolesivity, Eur. J. Med. Chem., 40(2), 155.

Katritzky, A. R. ; Ress, C.W. (1984). Comprehensive Heterocyclic Chemistry, The Structure, Reactions, Synthesis and uses of Heterocyclic Compounds, 1st edn. Pergamon press Ltd., 2, 581p.

Kwong, F.Y.; Klapars, A. ; Buchwald, S.L. (2002). Copper-catalyzed Coupling of Alkylamines and Aryl Iodides: An Efficient system Even in an Air Atmosphere, Org. leff., 4, 581p. 
Maria, T.C.; Cenzo, C.; Valentina, L. ; Valentina, O. (2004). Synthesis of new N-(2(trifluoromethyl) pyridine-4-yl) anthranilic acid derivatives and their evalution as anticancer agents, Bioorg. Med. Chem. Letts., 14(23), 5787.

Mohammad, S. J. (1994). Preparation of a Number of Naphthyridinic Acids and Their Derivatives, M.Sc. Thesis, University of Mosul.

Nelson, D. ; Cox, M. (2000). Lehninger principles of biochemistry. 3rd edn. New York Worth Publishers.

Per, W. (2004). Synthesis of heterocycles from Anthranilic acid and its derivatives. M.Sc. Thesis, Stockholm, Sweden.

Skotnicki, J. S. ; Gilman, S.C.(1989). 2-Aryl benzo [b][1,8] naphthyidines as inhibitors of interleukin 1, (American hom products Gorp.) U.S. US4, 808, 612, (Cl. 514-290; A61 K31/44), Appl. 47, 970, 8., C.A.1989.110, 231609m.

Tangaly, R.R.N.; Halehatty, S.B.N.; Raghavendra, M. ; Shaukarahalli, G.K.N.(2006). Synthesis of thieno [2,3-b] benzo [1,8] naphthyridine-2-carbacids under microwave irradiation and interaction with studies, http://www.arkatusa.org /ARKIVOC/JOURNAL_CONTENT/ manuscripts/ 2006/pp. 06-2216.

Tsuzuki, Y.; Yomita, K. ; Sato, Y. (2004). Synthesis and Structure activity relationship of 3Substetuted 1,4-dihydro-1,8-naphthyridine as novel antitumor agents, Bioorg. Med. Chem. Letts., 14, 1, 12(14, 12), 3189.

Vogel, A. I. (1972). A Text Book of Practical Organic Chemistry, 3rd edn. Longman, New Impressions, 991p.

Wolf, C.; Liu, S.; Mei, X.; August, A.T. ;Casimir, M.D. (2006). Regio selective Coppercatalyzed Amination of Bromo benzoic Acids Using Aliphatic and Aromatic Amines, J. Org. Chem.,71, 3270.

Zheny, X.Y.; Xia, Y.; Gao, F.H.; Gao, H.Z. ; Chen, C.(1979). Synthesis of 7351, a new antimalarial drug, Yao Hsuch Hsuch Pao, 14, 12, 736. C.A. 1980. 93, 132397. 